\title{
Source rocks of Carboniferous-Lower Cretaceous terrigenous sediments of the northeastern Siberian Platform: results of Sm-Nd isotope-geochemical studies
}

\author{
S.V. Malyshev ${ }^{\text {a,* }}$, A.K. Khudoley ${ }^{\text {a }, ~ A . V . ~ P r o k o p i e v ~}{ }^{\text {b }}$, V.B. Ershova ${ }^{\text {a }}$, G.G. Kazakova ${ }^{\text {c }}$, \\ L.B. Terentyeva ${ }^{\mathrm{d}}$ \\ ${ }^{\text {a } I n s t i t u t e ~ o f ~ E a r t h ~ S c i e n c e s, ~ S t . ~ P e t e r s b u r g ~ S t a t e ~ U n i v e r s i t y, ~ U n i v e r s i t e t s k a y a ~ n a b . ~ 7 / 9, ~ S t . ~ P e t e r s b u r g, ~ 199034, ~ R u s s i a ~}$ \\ ${ }^{\mathrm{b}}$ Diamond and Precious Metal Geology Institute, Siberian Branch of the Russian Academy of Sciences, pr. Lenina 39, Yakutsk, 677007, Russia \\ ${ }^{c}$ A.P. Karpinsky Russian Geological Research Institute (VSEGEI), Sredny pr. 74, St. Petersburg, 199106, Russia \\ ${ }^{\mathrm{d}}$ Institute of Precambrian Geology and Geochronology, nab. Makarova 2, St. Petersburg, 199034, Russia
}

Received 28 August 2014; accepted 4 March 2015

\begin{abstract}
The first Sm-Nd isotope studies of the Carboniferous-Early Cretaceous clastic rocks of the northeastern Siberian Platform have been carried out. Variation in the isotope composition of sediments within this time interval has been determined and interpreted. The high $\varepsilon_{\mathrm{Nd}}(t)$ values for Carboniferous-Permian sediments (from -11 to -2) testify to the large contribution of the products of erosion of island-arc and juvenile complexes localized in the Taimyr-Severnaya Zemlya fold-thrust belt in the Carboniferous. The positive $\varepsilon_{\mathrm{Nd}}(t)$ values for Triassic sandstones suggest erosion of the coeval igneous rocks of the trap association. The Upper Jurassic and, particularly, Cretaceous sediments of the Lena-Anabar depression and Verkhoyansk foreland basin are characterized by extremely negative $\varepsilon_{\mathrm{Nd}}(t)$ values (from -15 to -19 ), which is evidence for erosion of mature continental crust. The Carboniferous-Triassic complexes of the Verkhoyansk fold-thrust belt, which show higher $\varepsilon_{\mathrm{Nd}}(t)$ values, cannot have been a source of detritus for Cretaceous sandstones. The sediments filling the Verkhoyansk foreland basin accumulated as a result of the decomposition of homogenized distal source rocks with the isotope characteristics of the old crust rather than the breakup of the mountain range rising to the east. Salients of the crystalline basement of the Siberian Platform, such as the Aldan Shield, might have been these source provinces.
\end{abstract}

(C) 2016, V.S. Sobolev IGM, Siberian Branch of the RAS. Published by Elsevier B.V. All rights reserved.

Keywords: Carboniferous; Permian; Mesozoic; $\varepsilon_{\mathrm{Nd}}$; source rocks; Verkhoyansk foreland basin; Verkhoyansk passive margin; Siberian continent

\section{Introduction}

The Late Paleozoic and Mesozoic sedimentary basins in the northeastern Siberian Platform are composed of the terrigenous sediments of the passive margin and marginal troughs. The composition of the terrigenous sediments depends on many factors, the most important being the characteristics of source rocks: the composition of eroded rocks, the position of some rocks with respect to the others, and distance from the sedimentary basin. Change in the composition of the clastic material supplied to the basin reflects a change of the paleogeographic environment and of the configuration of the sources, which, in turn, is related to large regional tectonic

\footnotetext{
* Corresponding author.

E-mail address: sergey.v.malyshev@gmail.com (S.V. Malyshev)
}

events. Studies of different sedimentary basins show the efficiency of the Sm-Nd method for the determination of the characteristics of source rocks (Boghossian et al., 1996; Podkovyrov et al., 2007; Ross et al., 1997, 2005). During sedimentation processes, such as erosion, transport, and accumulation, REE are retained in the detrital fraction in the same proportions as in source rocks (McLennan et al., 1993, 2003). As $\mathrm{Sm}$ and $\mathrm{Nd}$ are $\mathrm{REE}$, the isotope characteristics of whole rock samples of clastic rocks must reflect the weighted mean characteristics of source rocks.

The aim of the paper is to reconstruct the source rocks of Carboniferous-Cretaceous sedimentary basins in the northeastern Siberian Platform, based on the study of the $\mathrm{Sm}-\mathrm{Nd}$ isotope system in terrigenous rocks. Information on the regional source rocks is based mainly on the study of sandstones, including their heavy fraction (Egorov et al., 2001; Kaplan, 1976; Mezhvilk and Markov, 1983). Despite the 
enormous quantity of data, their interpretation is often complicated, because it is impossible to identify the tectonic origin or age of the source rocks. The results of $\mathrm{U}-\mathrm{Pb}$ dating of detrital zircons are more informative, but they are not abundant as yet and concern only some fragments of the section (Ershova et al., 2013, 2015; Miller et al., 2013; Prokopiev et al., 2013). On the other hand, the rock material collected by the authors permits describing the entire terrigenous section considered in the paper and tracing the main trends in the evolution of the source rocks.

\section{Geological summary}

The Upper Paleozoic and Mesozoic sediments on the northeastern margin of the Siberian Platform were studied in outcrops and boreholes within the Olenek uplift, Olenek folded zone, Lena-Anabar depression, Verkhoyansk foreland basin, and Verkhoyansk fold-thrust belt (Figs. 1,2). Permian and Triassic platform sediments are observed within the Olenek uplift. They are overlain by Jurassic and Cretaceous sediments, which are localized mainly in the troughs north and east of the Olenek uplift. At the place of the principal sedimentary basin in which Carboniferous-Triassic sediments accumulated-the Verkhoyansk passive continental margin, the Verkhoyansk fold-thrust belt is localized, fringing the eastern Siberian Platform.

The Carboniferous System. The Carboniferous sediments have a limited distribution over the platform within the Olenek uplift but are widespread in the northern Kharaulakh Ridge (northern Verkhoyansk area). Only Tournaisian and Lower Visean carbonate sediments are known in the Olenek uplift. In the Kharaulakh Ridge, Tournaisian shallow-water carbonate sediments are overlain by the terrigenous sediments of the Verkhoyansk complex. The section of the latter begins with a Visean series of variable facies, in which boulder conglomerates are laterally replaced by cherty mudstones. They are overlain by siltstones and mudstones, which contain sandstone beds above in the section. In general, the grain size of the terrigenous rocks increases gradually up the section. The sedimentation took place under shelf, delta, and submarine-fan conditions (Egorov et al., 2001; Ershova et al., 2013; Parfenov, 1984; Prokopiev et al., 2001, 2013). The estimated total thickness of the Carboniferous terrigenous sediments is $>2000 \mathrm{~m}$ (Egorov et al., 2001).

The Permian System ${ }^{1}$. The Permian sediments within the northeastern Siberian Platform and Verkhoyansk fold-thrust belt form a wedge whose thickness increases northward and eastward from $70-80 \mathrm{~m}$ in the Olenek uplift to $\sim 2365 \mathrm{~m}$ in the northern Lena-Anabar depression (Ust'-Olenek borehole) and $>2800 \mathrm{~m}$ in the Kharaulakh Ridge (Kontorovich et al., 2013; Mezhvilk and Markov, 1983; Prokopiev et al., 2001). Near the Olenek uplift, Lower Permian sediments unconformably overlie different horizons of Neoproterozoic, Mesopro-

\footnotetext{
${ }^{1}$ A binary division of the Permian Period is applied in the paper, because maps with such a division were used in field studies during sampling.
}

terozoic, and Cambrian rocks; in the Ust'-Olenek borehole, they overlie Silurian rocks. In the northern part of the Kharaulakh Ridge, they conformably overlie Upper Carboniferous beds; in the southern one, Upper Cambrian carbonate rocks.

The Permian sediments are terrigenous; within the platform, they are mainly quartz-feldspar sandstones interbedded with clastic material with different grain sizes, from siltstones to conglomerates of continental and littoral marine origins. The section contains coal measures, and ripple marks are often observed on the surface of the sandstones. Toward the platform edges (in the Verkhoyansk foreland basin, Lena-Anabar depression, and northern Verkhoyansk area), the rocks become finer grained, with a transition to shelf and deltaic sedimentation conditions-shallower water conditions than those for the Carboniferous sediments. Shallower water and coarser grained Permian sediments are observed above in the section. Such a structure of the section of the terrigenous complex is explained by the successive eastward progradation of submarine fans (Egorov et al., 2001; Mezhvilk and Markov, 1983; Parfenov, 1984; Prokopiev et al., 2001).

The Triassic System. At the Permian/Triassic boundary, a uniquely large-scale eruption of basalts (Siberian Traps) occurred in the platform. They are observed mainly within the Tunguska syneclise; in the northeastern part of the platform, mafic effusive traps are widespread south of the Olenek uplift (Kropachev, 2013). The Triassic sediments occur in the entire study area; their thickness increases quickly northeastward from $\sim 150 \mathrm{~m}$ on the slope of the Olenek uplift to $800 \mathrm{~m}$ on the northern limb of the Lena-Anabar depression and $2000 \mathrm{~m}$ in the northern Verkhoyansk area (Dagis and Kazakov, 1984; Egorov et al., 2001; Kazakov et al., 2002; Mezhvilk and Markov, 1983; Prokopiev et al., 2001).

The accumulation of the Triassic sediments, which unconformably overlie the Permian sediments, includes several periods of transgression and regression, reflected in the completeness of the stratigraphic section and in the sediment composition (Dagis and Kazakov, 1984; Kazakov et al., 2002). The sedimentation took place predominantly under shelf and delta conditions. In the western part of the study region, the transition from marine to continental conditions began in the late Middle Triassic. Except the Olenek marker horizon of limestones, the rocks are terrigenous, with some tuffaceous material or the products of erosion of mafic igneous rocks. In the Lena-Anabar depression, Induan beds are preserved mainly in the basins, whereas the Triassic section in the uplifts begins with the Olenek Stage. The Middle Triassic sediments occur on the northern limb of the Lena-Anabar depression and along the boundary of the fold-thrust structures of the northern Verkhoyansk area and Verkhoyansk foreland basin, but they are missing in the platform. The underlying beds of the Upper Triassic sediments are eroded. The Upper Triassic is complete only in the Olenek folded area, while only the Carnian marine sediments are preserved near the Olenek uplift and in the Verkhoyansk foreland basin.

The Jurassic System. The Jurassic terrigenous sediments transgressively overlap the Triassic, Upper Paleozoic, and 


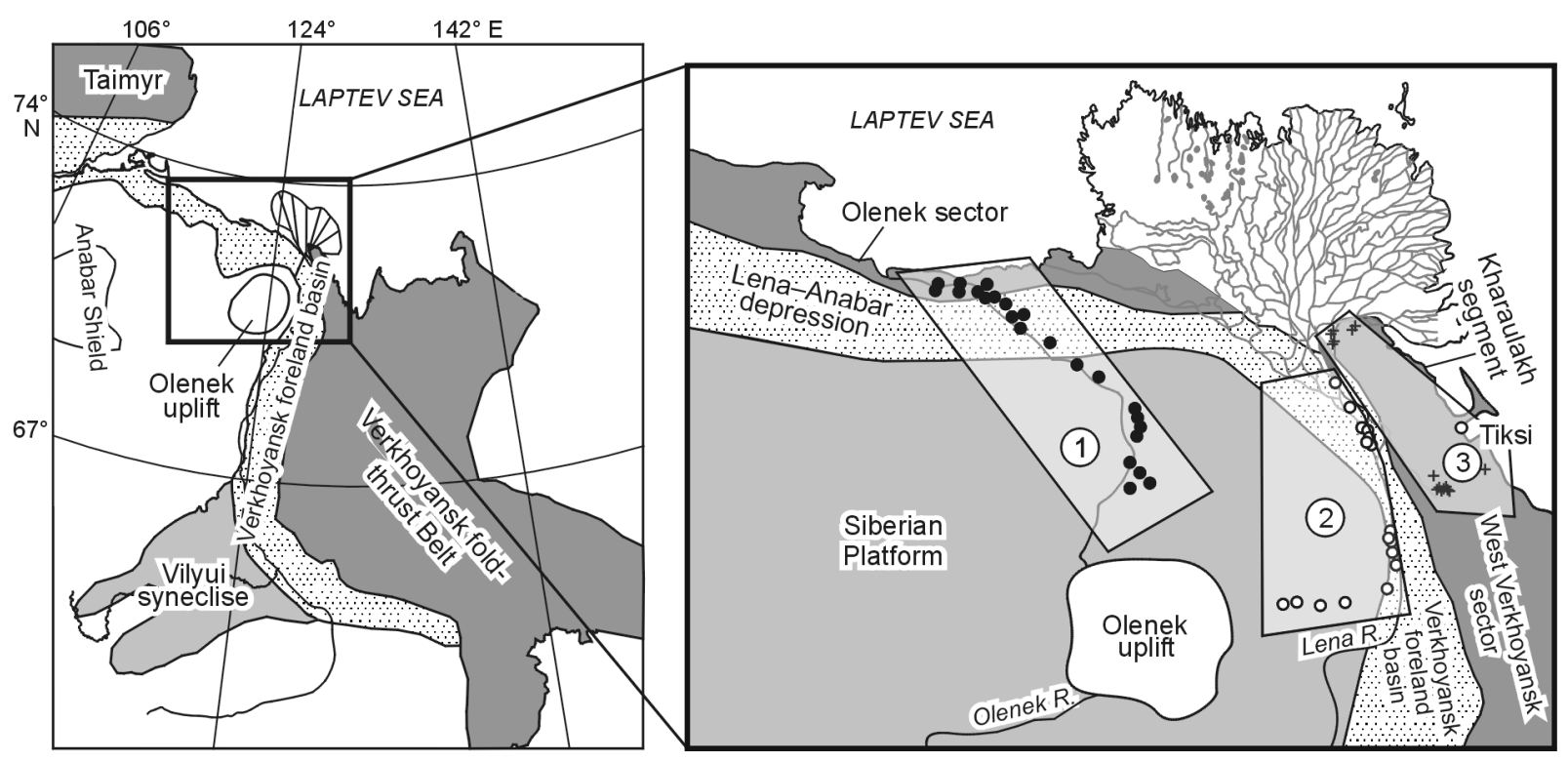

Fig. 1. Regional sketch map, with study areas and sampling sites. 1, Olenek; 2, Lena; 3, Kharaulakh areas. Black circles show samples from the Olenek area; white circles, from the Lena area; and crosses, from the Kharaulakh area.

Cambrian rocks. The uppermost Jurassic horizons are observed in the Verkhoyansk foreland basin and Lena-Anabar depression, in the central part of which they are overlain by Cretaceous sediments. The Bajocian clayey sediments are overlain by Bathonian-early Callovian delta sandy and siltsandy rocks. The Callovian sediments are mudstones and siltstones in the northern Lena-Anabar depression and sandstones on its southern limb. The near-platform part lacks Oxfordian or Kimmeridgian rocks because of their erosion during the pre-Volgian gap. The Oxfordian and Kimmeridgian sediments in the Verkhoyansk foreland basin are thin members of fine-grained sandstones and siltstones. The Tithonian Stage is composed of marine clay-siltstone and siltstone-sandy rocks. The total thickness of the Jurassic sediments is $\sim 1000 \mathrm{~m}$ in the Lena-Anabar depression and the platform limb of the Verkhoyansk foreland basin and at least two times larger in the Verkhoyansk foreland basin (Egorov et al., 2001; Knyazev et al., 1991; Mezhvilk and Markov, 1983; Prokopiev et al., 2001; Rogov et al., 2011; Shurygin et al., 2000).

The Cretaceous System. The Cretaceous sediments fill the central Lena-Anabar depression and the Verkhoyansk marginal trough. They have the maximum thickness $(\leq 4500 \mathrm{~m})$ near the front of the Verkhoyansk fold-thrust belt, which decreases quickly (to several hundred meters) toward the platform. The Lower Cretaceous sediments belong to the marine, littoral marine, and continental facies. The transition from marine to continental sediments in the study area occurred in the Valanginian (Devyatov et al., 2011). The continental sediments in the Verkhoyansk foreland basin are divided into two alternating types. Type 1 is a succession of amalgamated channels (Ershova et al., 2010) composed of medium- and coarse-grained white to light gray arkoses. Type 2 includes clays and siltstones with rare sandstone interbeds and lenses, which are the sediments of abandoned channels, crevasse glyphs, and bogs (Ershova et al., 2010).
The presence of Upper Cretaceous sediments is disputable; they might be localized in the central Lena-Anabar depression as continental coarse-grained sandstones with coal measures (Egorov et al., 2001; Khudoley and Prokopiev, 2007; Mezhvilk and Markov, 1983; Prokopiev et al., 2001).

\section{Analytical methods and objects of study}

The goal of our study was to reconstruct the source rocks of terrigenous series in several structure-facies zones of the northeastern Siberian Platform: Olenek folded zone, Lena-Anabar depression, Verkhoyansk foreland basin, northern Verkhoyansk fold-thrust belt, and platform cover. Representative samples of Carboniferous-Cretaceous terrigenous rocks were used for $\mathrm{Sm}-\mathrm{Nd}$ isotope-geochemical studies. In total, 66 samples were analyzed; to facilitate the subsequent description of results, we divided the study area into three geographic areas: Olenek, Lena, and Kharaulakh. From the Olenek and Lena areas, Permian-Early Cretaceous samples were studied; from the Kharaulakh area, Carboniferous-Permian ones (Fig. 1).

Samarium and neodymium contents and isotope compositions were determined at the Institute of Precambrian Geology and Geochronology (St. Petersburg) using a TRITON TI multicollector mass spectrometer in a static mode. The measured ${ }^{143} \mathrm{Nd} /{ }^{144} \mathrm{Nd}$ ratios were corrected for isotopic fractionation based on the ratio ${ }^{146} \mathrm{Nd} /{ }^{144} \mathrm{Nd}=0.7219$ to ${ }^{143} \mathrm{Nd} /{ }^{144} \mathrm{Nd}=0.512117$ in the JNdi-1 standard. Blank experiment over the study period was $0.03-0.2 \mathrm{ng}$ for $\mathrm{Sm}$ and $0.1-0.5 \mathrm{ng}$ for $\mathrm{Nd}$. The accuracy of determination of Sm and $\mathrm{Nd}$ contents was $\pm 0.5 \%(2 \sigma)$; of the ${ }^{147} \mathrm{Sm} /{ }^{144} \mathrm{Nd}$ ratios, $\pm 0.5 \%$; and of the ${ }^{143} \mathrm{Nd} /{ }^{144} \mathrm{Nd}$ ratios, $\pm 0.005 \%$; $\varepsilon_{\mathrm{Nd}}(t)$ was calculated with the use of the present-day ratios ${ }^{143} \mathrm{Nd} /{ }^{144} \mathrm{Nd}=$ 0.512638 and ${ }^{147} \mathrm{Sm} /{ }^{144} \mathrm{Nd}=0.1967$ in the CHUR (Jacobsen 


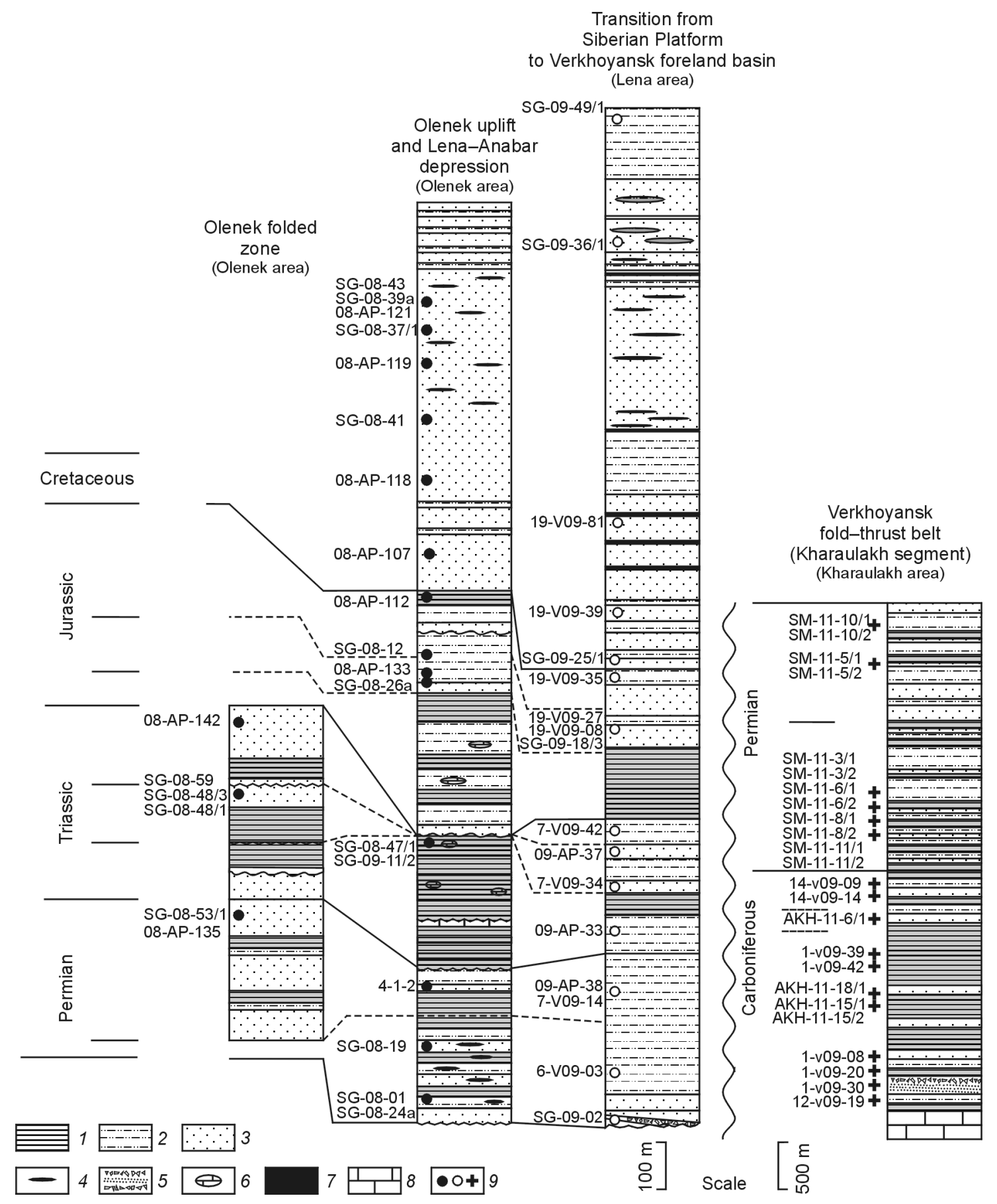

Fig. 2. Simplified chart of correlation between composite sections of outcrops, with sampling sites. See notation for the samples in Fig. 1. Simplified after (Dagis and Kazakov, 1984; Egorov et al., 2001; Kaplan, 1976; Kazakov et al., 2002; Mezhvilk and Markov, 1983; Prokopiev et al., 2001). 1, mudstones; 2, siltstones; 3 , sandstones; 4 , lenses; 5 , conglomerates; 6 , carbonate concretions; 7 , coals; 8 , carbonates; 9 , samples.

and Wasserburg, 1984). Thorium and scandium contents were determined in the VSEGEI central laboratory by ICP-MS.

\section{Sm-Nd isotope systematics of the terrigenous rocks}

Interpretation of Sm-Nd data for the sedimentary rocks. Samarium and neodymium are REE and belong to the series of radioactive decay. Radioactive isotope ${ }^{147} \mathrm{Sm}$ decays into ${ }^{143} \mathrm{Nd}$, as in
${ }^{143} \mathrm{Nd} /{ }^{144} \mathrm{Nd}=\left({ }^{143} \mathrm{Nd} /{ }^{144} \mathrm{Nd}\right)_{0}+\left({ }^{147} \mathrm{Sm} /{ }^{144} \mathrm{Nd}\right)\left(\mathrm{e}^{\lambda \mathrm{t}}-1\right)$,

where isotope ${ }^{144} \mathrm{Nd}$ is stable and the $\left({ }^{143} \mathrm{Nd} /{ }^{144} \mathrm{Nd}\right)_{0}$ ratio corresponds to the initial $\mathrm{Nd}$ isotope composition at the moment of the rock crystallization. The ${ }^{143} \mathrm{Nd} /{ }^{144} \mathrm{Nd}$ ratio (radiogenic to stable), which can change only owing to radioactive decay, is resistant to crustal geologic processes.

Rare-earth elements, except $\mathrm{Ce}$ and $\mathrm{Eu}$, have the same valence and only slightly different ionic radii, which explains their similar geochemical properties. Nevertheless, the slight 


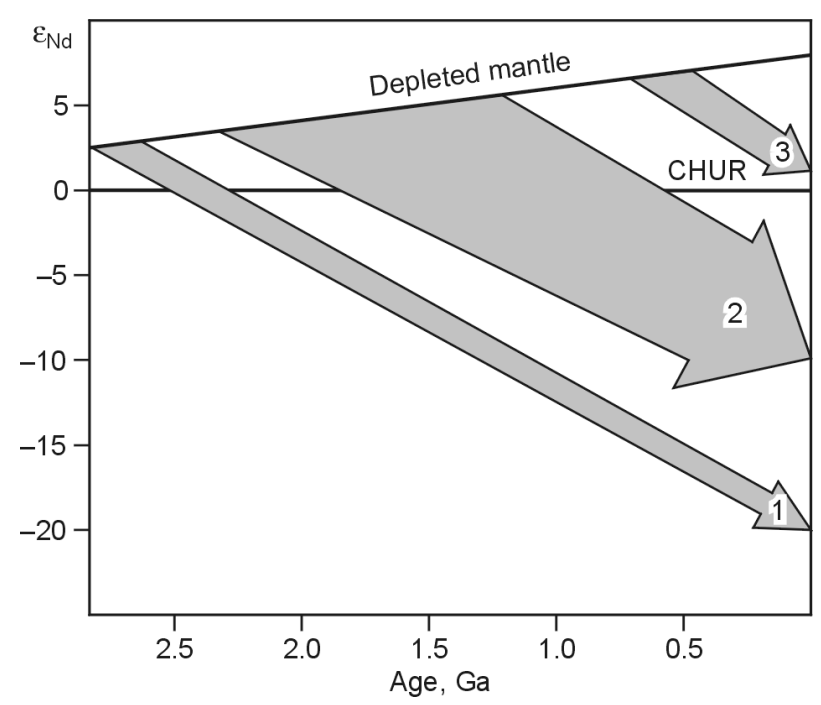

Fig. 3. Schematic diagram $\varepsilon_{\mathrm{Nd}}$-age, illustrating the simplest interpretations of the $\mathrm{Sm}-\mathrm{Nd}$ age of source rocks. Sample 1 has extremely low $\varepsilon_{\mathrm{Nd}}$, which corresponds to the isotope composition of the Archean crust. The samples belonging to field 2 with an $\varepsilon_{\mathrm{Nd}}$ value of about -12 to -5 consist of the products of erosion of Proterozoic source rocks. The isotope composition of sample 3 corresponds to that of juvenile source rocks. Note that the isotope composition of field 2 might correspond to the mixing of Archean and juvenile sources. The mixing effect can make isotope data on sedimentary rocks extremely hard to interpret (Ross et al., 1997).

difference between the $\mathrm{Sm}$ and $\mathrm{Nd}$ ionic radii $(\mathrm{Sm}=1.04 \AA$, $\mathrm{Nd}=1.08 \AA$ ) is enough for the $\mathrm{Sm} / \mathrm{Nd}$ pair to fractionate during partial melting and crystallization. Partial melting generates magmas with lower $\mathrm{Sm} / \mathrm{Nd}$ ratios than those in the initial reservoir; therefore, the rocks forming from such magmas have lower ${ }^{143} \mathrm{Nd} /{ }^{144} \mathrm{Nd}$ ratios. The depleted reservoir zones remaining after the removal of the partial melts have higher $\mathrm{Sm} / \mathrm{Nd}$ ratios and, respectively, higher ${ }^{143} \mathrm{Nd} /{ }^{144} \mathrm{Nd}$ ratios. The different magmatic histories and ages of the igneous rocks determine variations in the crustal ${ }^{143} \mathrm{Nd} /{ }^{144} \mathrm{Nd}$ ratios. A schematic diagram for interpreting $\mathrm{Nd}$ data for sedimentary rocks is shown in Fig. 3. To interpret $\mathrm{Sm}-\mathrm{Nd}$ data, it is customary to use parameter $\varepsilon_{\mathrm{Nd}}(t)$, which shows the difference of the ${ }^{143} \mathrm{Nd} /{ }^{144} \mathrm{Nd}$ ratio in the sample from that in the CHUR at the specific moment, or $\varepsilon_{\mathrm{Nd}}(0)$, which shows the present difference of the ${ }^{143} \mathrm{Nd} /{ }^{144} \mathrm{Nd}$ ratio in the sample from that in the CHUR (DePaolo and Wasserburg, 1976; Jacobsen and Wasserburg, 1984).

The numerous studies summarized in (McLennan et al., 1993, 2003; Taylor and McLennan, 1985) show that REE are not changed by metamorphic or sedimentary (weathering, transport, deposition, and diagenesis) processes. Therefore, $\mathrm{Nd}$ isotope composition in sedimentary rock corresponds to that in the sources. If we consider the short geological time of Sm and $\mathrm{Nd}$ presence in water ( 400 years (Banner, 2004)), the isotope composition of the sediments of one basin is influenced only by the local source rocks or distal source rocks, the products of whose decomposition are transported to the basin by river systems. Variations in the isotope composition of water in the present-day oceans depending on their source provinces are shown in Fig. 4. Also, the isotope composition of sedimentary sequences can vary over time depending on the presence of new source rocks. As illustrated by the Phanerozoic schists (Fig. 5) in the submontane trough of the French Alps, the mantle component of these rocks was added during the orogenic events (Michard et al., 1985); i.e., source rocks with mantle $\mathrm{Nd}$ isotope composition originate during orogenic episodes, thus increasing the ${ }^{143} \mathrm{Nd} /{ }^{144} \mathrm{Nd}$ ratio.

Results. Results of Sm-Nd isotope-geochemical studies of the Carboniferous-Lower Cretaceous terrigenous rocks are summarized in Tables $1-3$. The $\varepsilon_{\mathrm{Nd}}(t)$ values for the terrigenous-rock samples under study and for possible source rocks are presented in Figs. 6 and 7.

The analyzed Carboniferous samples were recovered in the northern and southern Kharaulakh area. As regards the Sm-Nd isotope characteristics of the samples from the northern part of the area, these rocks have widely varying $\varepsilon_{\mathrm{Nd}}(t)$ values (from -10.4 to -1.3 ), whereas the $\varepsilon_{\mathrm{Nd}}(t)$ values for four samples from the southern part vary within a narrow range of -3.6 to -2.2 . The Permian samples have a more homogeneous

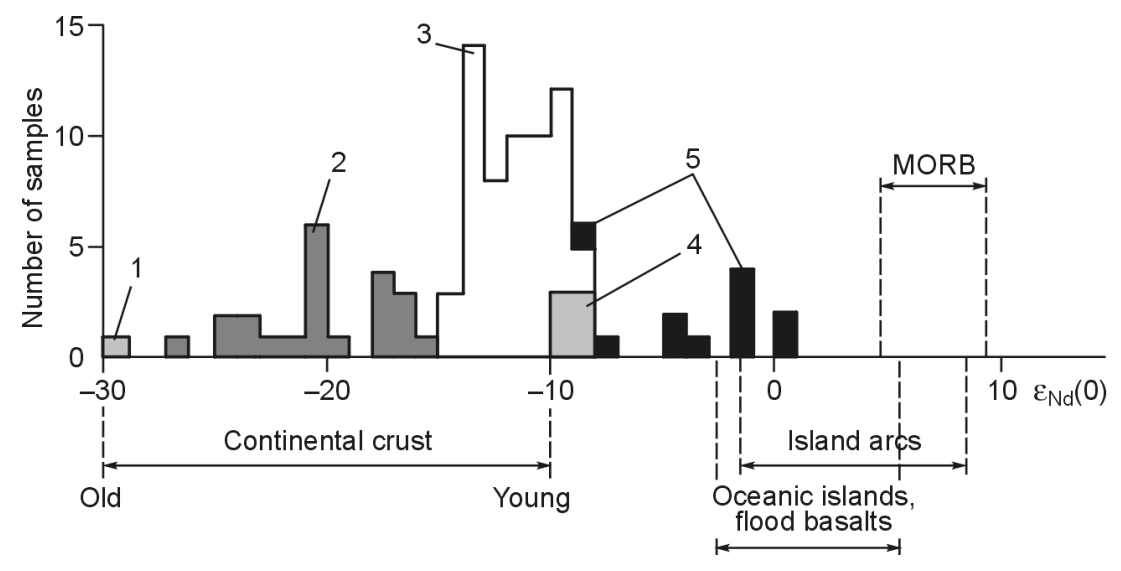

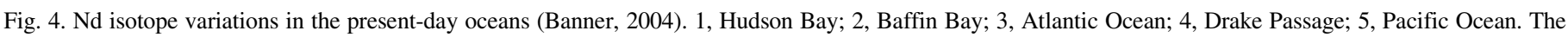

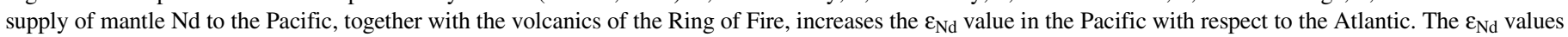
in the Drake Passage reflect the mixing of the Pacific and Atlantic waters. The low $\varepsilon_{\mathrm{Nd}}$ values in Hudson nad Baffin Bays are evidence for local old sources. 


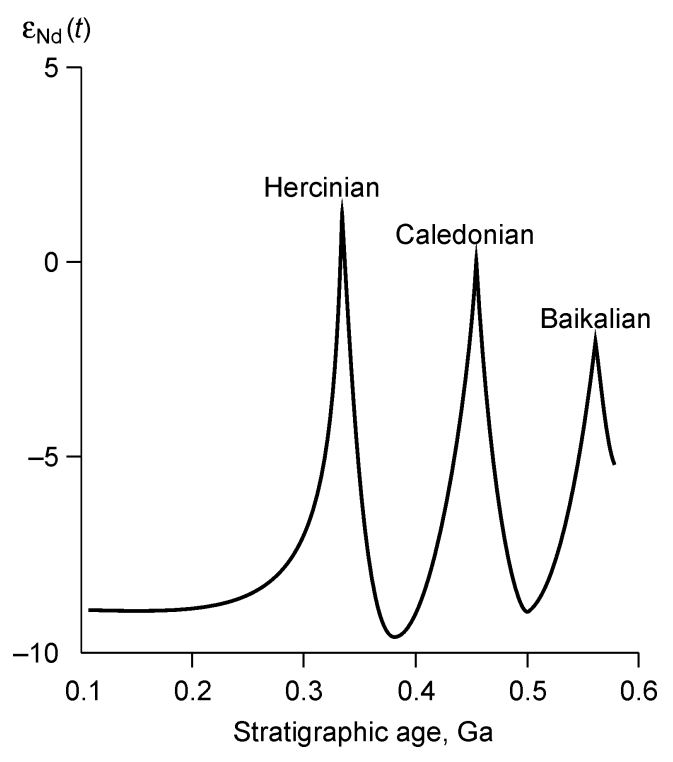

Fig. 5. The $\varepsilon_{\mathrm{Nd}}$ values for the sedimentary rocks in the foothills of the French Alps (Michard et al., 1985). The orogenic events (Hercynian, Caledonian, and Baikalian folding) correlate with increased $\varepsilon_{\mathrm{Nd}}$ values, whereas the average $\varepsilon_{\mathrm{Nd}}$ values during nonorogenic time are -10 . This is because mantle rocks were in the eroded area during the orogenic events.
$\mathrm{Nd}$ isotope composition, with $\varepsilon_{\mathrm{Nd}}(t)$ values of -6 to -3 , except two samples with more negative values $(-12$ and -11$)$.

The Triassic samples from the Olenek and Lena areas are characterized by similar $\varepsilon_{\mathrm{Nd}}(t)$ values $(-6$ to +1$)$. The increase in $\varepsilon_{\mathrm{Nd}}(t)$ in the Triassic might be related to the presence of the products of erosion of more juvenile material in the sedimentary basin. The Jurassic sediments show a wide range of $\varepsilon_{\mathrm{Nd}}(t)$ values (from -12 to -2 ). Through the Jurassic, the $\varepsilon_{\mathrm{Nd}}(t)$ values decreased gradually to the basement values, suggesting a change of the source rocks. The influence of different source rocks on different basin parts in the Jurassic is demonstrated by the difference in the $\varepsilon_{\mathrm{Nd}}(t)$ values for the Jurassic samples from the Olenek and Lena areas. The Cretaceous sandstones from the Olenek and Lena areas have homogeneous isotope characteristics with crustal $\varepsilon_{\mathrm{Nd}}(t)$ values $(-15$ to -19$)$.

On the $\varepsilon_{\mathrm{Nd}}(t)-\mathrm{Th} / \mathrm{Sc}$ diagram (Fig. 7), the points for the Cretaceous samples form a separate group with lower $\varepsilon_{\mathrm{Nd}}(t)$ values and the $\mathrm{Th} / \mathrm{Sc}$ ratio of $\sim 1.0$, which corresponds to the characteristics of the old crust. The compositional points of the Carboniferous-Jurassic samples plot along the line of mixing of island-arc complexes and upper-crust source rocks. They include the points for the Triassic rocks, which are

Table 1. Results of Sm-Nd isotope-geochemical studies of terrigenous samples from the Kharaulakh area

\begin{tabular}{|c|c|c|c|c|c|c|c|c|c|c|c|}
\hline \multirow[t]{2}{*}{ Sample no. } & \multirow[t]{2}{*}{ Rock type } & \multirow{2}{*}{$\begin{array}{l}\text { Stratigraphic } \\
\text { age }\end{array}$} & \multirow[t]{2}{*}{ Age, Ma } & $\mathrm{Sm}$ & $\mathrm{Nd}$ & \multirow[t]{2}{*}{${ }^{147} \mathrm{Sm} /{ }^{144} \mathrm{Nd}$} & \multirow[t]{2}{*}{${ }^{143} \mathrm{Nd} /{ }^{144} \mathrm{Nd}$} & \multirow[t]{2}{*}{$\varepsilon_{\mathrm{Nd}}(0)$} & \multirow[t]{2}{*}{$\varepsilon_{\mathrm{Nd}}(t)$} & $\mathrm{Th}$ & $\mathrm{Sc}$ \\
\hline & & & & $\mathrm{ppm}$ & & & & & & $\mathrm{ppm}$ & \\
\hline
\end{tabular}

\section{Carboniferous}

AKH-11-15/2

AKH-11-18/1

AKH-11-06/1

$1-\mathrm{v} 09-08$

1-v09-20

1-v09-30

1-v09-39

1-v09-42

12-v09-19

14-v09-09

14-v09-14

Permian

SM-11-03/1

SM-11-03/2

SM-11-06/1

SM-11-06/2

SM-11-11/1

SM-11-11/2

SM-11-05/1

SM-11-05/2

SM-11-10/1

SM-11-10/2

\section{Mudstone}

Sandstone

$\mathrm{C}_{1-2}$

$\mathrm{C}_{1-2}$

Mudstone

$\mathrm{C}_{1-2}$

Mudstone

$\mathrm{C}_{2-3}$

Sandstone

$\mathrm{C}_{1 \mathrm{~V}}$

Mudstone

$\mathrm{C}_{1} \mathrm{~V}$

Sandstone

$\mathrm{C}_{1} \mathrm{v}$

Mudstone

$\mathrm{C}_{1-2}$

Siltstone

Mudstone

$\mathrm{C}_{1-2}$

$\mathrm{C}_{1} \mathrm{v}$

Siltstone

Sandstone

$\mathrm{C}_{2-3}$

$\mathrm{C}_{2-3}$

Mudstone

Sandstone

$\mathrm{P}_{1}$

Mudstone

$\mathrm{P}_{1}$

Sandstone

$\mathrm{P}_{1}$

Mudstone

$\mathrm{P}_{1}$

$\mathrm{P}_{1}$

Sandstone

$\mathrm{P}_{1}$

Mudstone

$\mathrm{P}_{2}$

Sandstone

$\mathrm{P}_{2}$

Mudstone

$\mathrm{P}_{2}$

Sandstone

$\mathrm{P}_{2}$

$\begin{array}{lll}6.02 & 33.97 & 0.1072 \\ 6.19 & 33.82 & 0.1106 \\ 5.81 & 35.79 & 0.0981 \\ 6.59 & 34.62 & 0.1150 \\ 4.14 & 19.29 & 0.1297 \\ 5.20 & 24.15 & 0.1300 \\ 2.48 & 12.27 & 0.1220 \\ 4.73 & 22.56 & 0.1267 \\ 6.49 & 26.31 & 0.1491 \\ 3.92 & 19.31 & 0.1227 \\ 5.92 & 32.53 & 0.1099 \\ 6.91 & 32.51 & 0.1286\end{array}$

$0.512325 \pm 1$
$0.512260 \pm 3$
$0.512304 \pm 2$
$0.512334 \pm 2$
$0.512142 \pm 4$
$0.512425 \pm 3$
$0.512188 \pm 3$
$0.512022 \pm 2$
$0.512080 \pm 2$
$0.512299 \pm 3$
$0.511928 \pm 5$
$0.512092 \pm 3$

$-6.1$

$-2.2$

12.8

9.6

$-7.4$

$\begin{array}{lll}-3.6 & 9.9 & 5.9\end{array}$

340

320

330

$$
330
$$

330

330

330

330

$$
310
$$

310

6.91

33.84

$\begin{array}{lll}6.39 & 33.84 & 0.1141 \\ 6.01 & 31.59 & 0.1151 \\ 6.49 & 32.98 & 0.1191 \\ 5.00 & 24.69 & 0.1225 \\ 4.96 & 22.77 & 0.1377 \\ 4.89 & 23.98 & 0.1233 \\ 4.93 & 23.63 & 0.1260 \\ 3.25 & 17.66 & 0.1112 \\ 6.87 & 36.38 & 0.1142 \\ 4.51 & 22.61 & 0.1206\end{array}$

$\begin{array}{ll}0.512337 \pm 1 & -5.9 \\ 0.512315 \pm 1 & -6.3 \\ 0.512356 \pm 2 & -5.5 \\ 0.512336 \pm 3 & -5.9 \\ 0.512370 \pm 3 & -5.2 \\ 0.512351 \pm 2 & -5.6 \\ 0.512375 \pm 2 & -5.1 \\ 0.512313 \pm 2 & -6.3 \\ 0.512342 \pm 3 & -5.8 \\ 0.512345 \pm 3 & -5.7\end{array}$

-3.0
-3.4
-3.3
-3.0
-3.0
-2.8
-3.5
-3.2

$\begin{array}{ll}-3.0 & 12.0\end{array}$

$11.4-7.2$

275

275

275

275

275

260

260

250

22.61

$0.512345 \pm 3$

$-2.8$

$11.1 \quad 12.6$

$\begin{array}{lll}-3.3 & 8.7 & 9.2\end{array}$

$\begin{array}{lll}-3.0 & 12.2 & 9.1\end{array}$

$\begin{array}{lll}-3.0 & 9.4 & 5.0\end{array}$

$\begin{array}{lll}-2.8 & 7.1 & 8.8\end{array}$

$\begin{array}{lll}-3.5 & 5.0 & 4.5\end{array}$

$\begin{array}{lll}-3.2 & 10.8 & 16.5\end{array}$

$\begin{array}{lll}-3.3 & 7.6 & 9.2\end{array}$ 
Table 2. Results of Sm-Nd isotope-geochemical studies of terrigenous samples from the Lena area

\begin{tabular}{|c|c|c|c|c|c|c|c|c|c|c|c|}
\hline \multirow[t]{2}{*}{ Sample no. } & \multirow[t]{2}{*}{ Rock type } & \multirow{2}{*}{$\begin{array}{l}\text { Stratigraphic } \\
\text { age }\end{array}$} & \multirow{2}{*}{ Age, Ma } & \multirow{2}{*}{$\frac{\mathrm{Sm}}{\mathrm{ppm}}$} & \multirow[t]{2}{*}{$\mathrm{Nd}$} & \multirow[t]{2}{*}{${ }^{147} \mathrm{Sm} /{ }^{144} \mathrm{Nd}$} & \multirow[t]{2}{*}{${ }^{143} \mathrm{Nd} /{ }^{144} \mathrm{Nd}$} & \multirow[t]{2}{*}{$\varepsilon_{\mathrm{Nd}}(0)$} & \multirow[t]{2}{*}{$\varepsilon_{\mathrm{Nd}}(t)$} & Th & \multirow[t]{2}{*}{$\mathrm{Sc}$} \\
\hline & & & & & & & & & & ppm & \\
\hline \multicolumn{12}{|l|}{ Permian } \\
\hline SG-09-02 & Sandstone & $\mathrm{P}_{1}$ & 285 & 3.87 & 26.79 & 0.0874 & $0.512145 \pm 5$ & -9.6 & -5.6 & 5.9 & 6.0 \\
\hline 6-V09-03 & Sandstone & $\mathrm{P}_{1}$ & 285 & 4.05 & 29.99 & 0.0816 & $0.511883 \pm 6$ & -14.7 & -10.6 & 7.9 & 6.4 \\
\hline 09-AP-38 & Sandstone & $\mathrm{P}_{2}$ & 265 & 3.00 & 20.32 & 0.0846 & $0.512276 \pm 6$ & -7.3 & -3.6 & 5.3 & 4.1 \\
\hline 7-09V-14 & Mudstone & $\mathrm{P}_{2}$ & 265 & 5.60 & 42.46 & 0.0798 & $0.512200 \pm 3$ & -8.5 & -4.6 & 10.9 & 13.2 \\
\hline \multicolumn{12}{|l|}{ Triassic } \\
\hline SG-09-11/2 & Sandstone & $\mathrm{T}_{1} \mathrm{ol}$ & 247 & 2.78 & 16.76 & 0.1002 & $0.512394 \pm 5$ & -4.8 & -1.7 & 4.2 & 8.9 \\
\hline 09-AP-33 & Sandstone & $\mathrm{T}_{1} \mathrm{ol}$ & 247 & 4.01 & 26.31 & 0.0921 & $0.512375 \pm 3$ & -5.1 & -1.8 & 6.9 & 12.1 \\
\hline 7-V09-34 & Sandstone & $\mathrm{T}_{2}$ an & 241 & 6.48 & 48.45 & 0.0808 & $0.512117 \pm 2$ & -10.2 & -6.6 & 13.6 & 13.8 \\
\hline 09-AP-37 & Sandstone & $\mathrm{T}_{3} \mathrm{k}$ & 231 & 3.73 & 21.94 & 0.1029 & $0.512489 \pm 3$ & -2.9 & -0.1 & 6.7 & 8.3 \\
\hline 7-V09-42 & Mudstone & $\mathrm{T}_{3} \mathrm{k}$ & 222 & 4.11 & 26.11 & 0.0951 & $0.512475 \pm 4$ & .3 .2 & -0.3 & 5.8 & 16.5 \\
\hline \multicolumn{12}{|l|}{ Jurassic } \\
\hline 19-V09-08 & Sandstone & $\mathrm{J}_{2} \mathrm{bt}$ & 169 & 3.39 & 24.19 & 0.0846 & $0.512276 \pm 3$ & -7.1 & -4.6 & 8.4 & 5.2 \\
\hline 19-V09-27 & Sandstone & $\mathrm{J}_{2} \mathrm{bt}$ & 169 & 4.23 & 31.43 & 0.0813 & $0.512174 \pm 4$ & -9.1 & -6.6 & 10.5 & 6.2 \\
\hline SG-09-18/3 & Sandstone & $\mathrm{J}_{2} \mathrm{kl}$ & 163 & 3.66 & 26.86 & 0.0824 & $0.512061 \pm 3$ & -11.3 & -8.9 & 7.5 & 5.5 \\
\hline 19-V09-35 & Mudstone & $\mathrm{J}_{3} \mathrm{t}$ & 145 & 4.52 & 36.98 & 0.0739 & $0.511928 \pm 2$ & -13.8 & -11.6 & 12.6 & 18.0 \\
\hline \multicolumn{12}{|l|}{ Cretaceous } \\
\hline 19-V09-39 & Sandstone & $\mathrm{K}_{1} \mathrm{~b}$ & 140 & 4.15 & 32.20 & 0.0779 & $0.511602 \pm 4$ & -20.2 & -18.1 & 10.1 & 5.9 \\
\hline SG-09-25/1 & Sandstone & $\mathrm{K}_{1} \mathrm{v}-\mathrm{h}$ & 134 & 4.93 & 42.51 & 0.0701 & $0.511586 \pm 4$ & -20.5 & -18.4 & 12.8 & 7.2 \\
\hline 19-V09-81 & Sandstone & $\mathrm{K}_{1} \mathrm{~h}$ & 132 & 3.26 & 22.17 & 0.0888 & $0.512560 \pm 5$ & -21.0 & -19.2 & 4.9 & 6.5 \\
\hline SG-09-36/1 & Sandstone & $\mathrm{K}_{1}$ ap & 125 & 2.87 & 20.02 & 0.0866 & $0.511696 \pm 3$ & -18.4 & -16.6 & 3.8 & 5.5 \\
\hline SG-09-49/1 & Sandstone & $\mathrm{K}_{1}$ ap & 119 & 2.55 & 17.31 & 0.0890 & $0.511739 \pm 4$ & -17.5 & -15.9 & 3.6 & 5.5 \\
\hline
\end{tabular}

displaced on the diagram toward the main sources in both characteristics $\left(\varepsilon_{\mathrm{Nd}}(t)\right.$ and $\left.\mathrm{Th} / \mathrm{Sc}\right)$ with respect to the other points. The points for the Permian and, to a smaller extent, Carboniferous and Jurassic samples cover a wider region on the diagram, being displaced toward the felsic component (along the $\mathrm{Th} / \mathrm{Sc}$ axis), which testifies to heterogeneous source rocks, including both more felsic rocks and juvenile material.

\section{Discussion}

Possible sources: the Siberian Platform and surrounding orogens. Most of the basement of the northern Siberian Platform consists of the Archean crust reworked during Paleoproterozoic tectonic events, when the Siberian Platform basement was formed by collision (Glebovitsky et al., 2008; Rosen et al., 2006; Smelov and Timofeev, 2007; Smelov et al., 2001). The Siberian Platform basement has Paleoproterozoic and Archean model ages $\left(T_{\mathrm{DM}}\right)$, with the predominance of the Archean ages and an $\varepsilon_{\mathrm{Nd}}(0)$ value of -16 or less, mostly below -25 (Gusev et al., 2013; Kovach et al., 2000; Molchanov et al., 2011; Rosen et al., 2006; Smelov et al., 2001, 2012). The Mesoproterozoic terrigenous sedimentary complexes have characteristics similar to those of the basement rocks; they have $\varepsilon_{\mathrm{Nd}}(0)$ values of -25 or less and Archean model ages $\left(T_{\mathrm{DM}}\right)$ (Khudoley et al., 2015; Kuptsova et al.,
2011). The overlying Meso- and Neoproterozoic and Lower Paleozoic platform sediments, to the Carboniferous strata, are dominated by carbonates. As a young source of detritus might be the Siberian Traps, widespread in the western part of the platform; their $\mathrm{Sm}-\mathrm{Nd}$ isotope characteristics are well-known: $\varepsilon_{\mathrm{Nd}}(t)$ for $250 \mathrm{Ma}$ is from -10 to +8 , peaking at 0 to +2 (GEOROC; Lightfoot et al., 1993).

The Sm-Nd isotope characteristics of the complexes from the surrounding fold-thrust belts were not studied everywhere, but some data are available. The Taimyr-Severnaya Zemlya belt is the fold-thrust belt closest to the study area; along with the Kara terrane, it includes Neoproterozoic juvenile rocks and Neoproterozoic to Triassic felsic, mafic, and alkalic igneous complexes, the products of whose erosion might be localized in the Upper Paleozoic and Mesozoic terrigenous complexes of the neighboring regions (Makar'ev, 2013; Proskurnin et al., 2014; Vernikovsky, 1996; Vernikovsky et al., 2003, 2004). The available data on the $\mathrm{Sm}-\mathrm{Nd}$ characteristics of the source rocks can be summarized as follows: The Neoproterozoic granites show $\varepsilon_{\mathrm{Nd}}(0)$ values of -14 to -7.7 (Vernikovskaya et al., 2002; Vernikovsky, 1996); the Late Permian and Early Triassic postcollisional granites, from -8 to +2 (Vernikovsky et al., 2003); and the Neoproterozoic plagiogranites, from -5.6 to +1.2 (Vernikovsky, 1996). 
Table 3. Results of Sm-Nd isotope-geochemical studies of terrigenous samples from the Olenek area

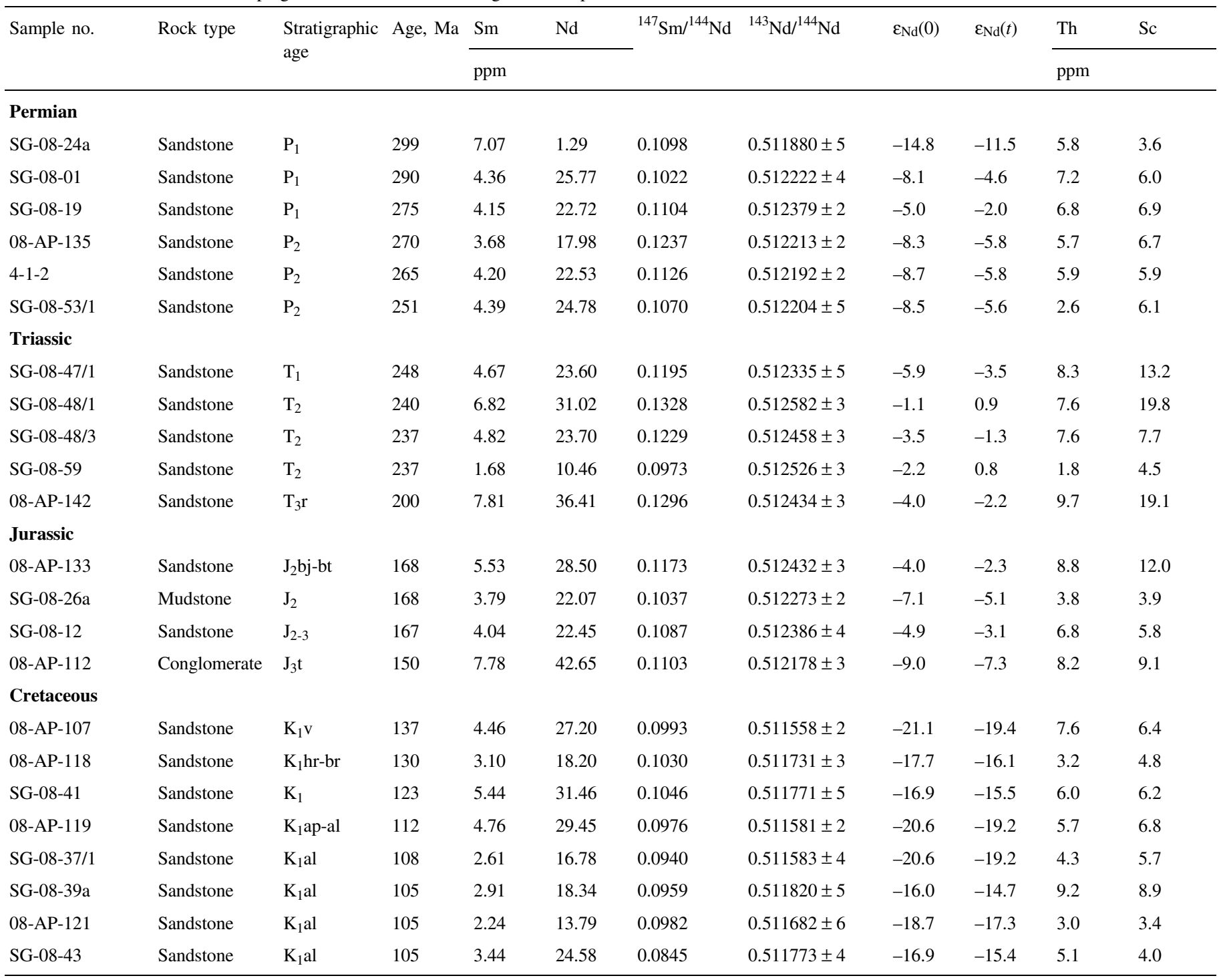

The Sm-Nd characteristics of some complexes on the southwestern margin of the Siberian Platform show a wide range of $\varepsilon_{\mathrm{Nd}}$ values. For example, the Neoproterozoic granites of the Yenisei Ridge have $\varepsilon_{\mathrm{Nd}}(0)$ values of -15 to -10 (Vernikovsky et al., 2007); the alkalic igneous complexes, from -6 to +1 (Romanova et al., 2012). Besides, considerable variations in the $\varepsilon_{\mathrm{Nd}}$ values, up to juvenile values, are observed in Transbaikalia and more westerly parts of the Central Asian Orogenic Belt, which are also possible source areas (Degtyarev, 2012; Kröner et al., 2014; Rytsk et al., 2007).

Thus, the fold belts framing the Siberian Platform have a heterogeneous $\mathrm{Nd}$ isotope composition with $\varepsilon_{\mathrm{Nd}}(0)$ values of predominantly -10 to +2 . If the old crust is present in the source area, the $\varepsilon_{\mathrm{Nd}}(0)$ values can decrease; in the presence of ophiolites, they can increase dramatically.

Source areas of the Carboniferous terrigenous rocks. The obtained $\mathrm{Sm}-\mathrm{Nd}$ isotope data for the Carboniferous samples show a nonuniform spatiotemporal distribution of the $\varepsilon_{\mathrm{Nd}}(t)$ values.
Two groups of Carboniferous samples from the Kharaulakh area (Table 1, Figs. 6, 8a) have different isotope characteristics. The northern part of the area is characterized by a wide range of $\varepsilon_{\mathrm{Nd}}(t)$ values, whereas in the more southerly part of the Kharaulakh anticlinorium, which is farther from the platform edge, the rocks have a homogeneous isotope composition with high $\varepsilon_{\mathrm{Nd}}(t)$ values $(-3.6$ to -2.2$)$, which reflect the presence of both island-arc complexes, including juvenile ones, and mature continental crust in the source area (Fig. 7). Judging by the regularities in the change of the composition and sedimentation conditions of the Carboniferous rocks, there was a sea basin northeast and east of the study region and detritus cannot have been transported from the east (Prokopiev et al., 2013). On the other hand, as shown by the ages of detrital zircons from the same sedimentary complexes, a significant part of the detritus was transported from the Taimyr-Severnaya Zemlya fold-thrust belt (Ershova et al., 2013, 2015; Prokopiev et al., 2013), from which the products of erosion of the island-arc and juvenile rocks might have been supplied (Fig. 8a). The sedimentation under conditions 


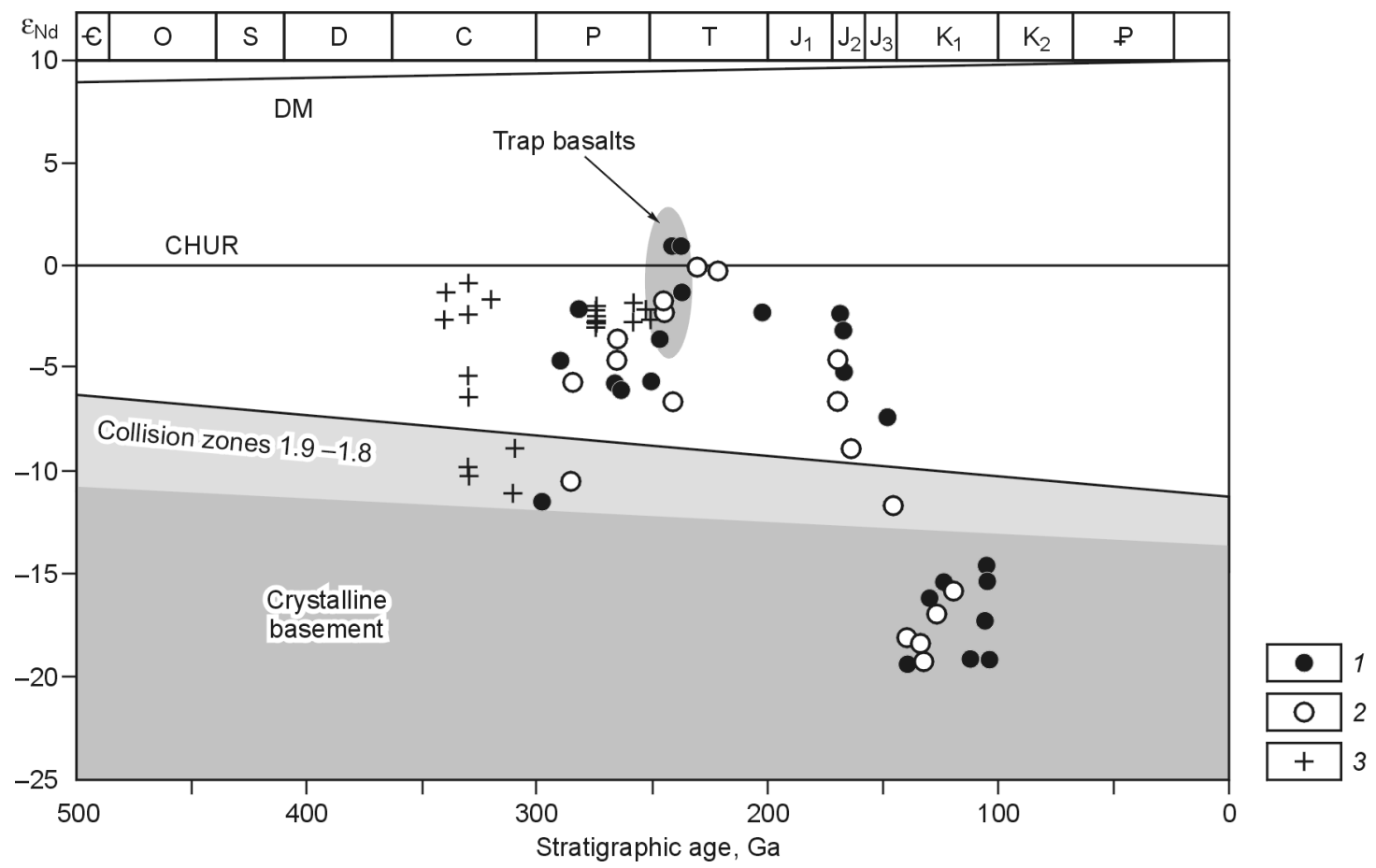

Fig. 6. Diagram for the evolution of the $\varepsilon_{\mathrm{Nd}}$ value for the Carboniferous-Lower Cretaceous terrigenous samples. 1, samples from the Olenek area; 2, from the Lena area; 3, from the Kharaulakh area. The field of values for the crystalline basement and Proterozoic crust is after (Glebovitsky et al., 2008; Kovach et al., 2000; Rosen et al., 2006), and the field of values for the trap basalts is after (GEOROC; Lightfoot et al., 1993).

of a submarine fan at a distance from the source area favored the homogenization of isotope composition. The rocks in the group of samples from the northern Kharaulakh area were localized closer to the source of detritus on the Taimyr Peninsula, as shown by the less homogeneous isotope composition of the terrigenous rocks (Fig. 8a). Most likely, the Siberian Platform basement was a source area with widespread mature continental crust, as it is also evidenced by the dating of the detrital zircons (Ershova et al., 2013, 2015; Prokopiev et al., 2013). Some low $\varepsilon_{\mathrm{Nd}}(t)$ values (to -10.4$)$ in the studied Carboniferous rocks might be related to the increase in the contribution of local source rocks with the old crust (first and foremost, the Olenek uplift).

Source areas of the Permian terrigenous rocks. The isotope composition of the sandstones and mudstones in the Permian sediments varies within the same range as that in the Carboniferous sediments $\left(\varepsilon_{\mathrm{Nd}}(t)\right.$ values of -11.5 to -2.0 , Fig. 6, Tables 1-3), suggesting a combination of island-arc and/or juvenile source rocks. Like the Carboniferous rocks, the Permian rocks have the most homogeneous isotope characteristics in the section of the inner part of the Kharaulakh anticlinorium, which is remote from the platform edge: The $\varepsilon_{\mathrm{Nd}}(t)$ values for ten Lower and Upper Permian samples vary only from -3.5 to -2.8 (Figs. $6,8 a$, Table 1). Within the Lena and Olenek areas, the $\varepsilon_{\mathrm{Nd}}(t)$ values vary from -10.6 to -3.6 and from -11.5 to -2.0 , respectively, reflecting the fact that the isotope characteristics of the terrigenous rocks become less homogeneous in the westward direction (Fig. 8a, Tables $2,3)$.
As in the Carboniferous, the Siberian Platform basement was a source area with widespread mature continental crust. Nevertheless, despite the similarity between the isotope characteristics of the Carboniferous and Permian terrigenous complexes, the rocks with high $\varepsilon_{\mathrm{Nd}}(t)$ values in the Permian sections are of disputable origin. In the Olenek basin, the coexistence of the sample in which $\varepsilon_{\mathrm{Nd}}(t)$ is -2.0 with the sample in which $\varepsilon_{\mathrm{Nd}}(t)$ equals -11.5 is related to unknown local sources with widespread mafic igneous rocks (Fig. 8a). Judging by the change of facies and thicknesses, the sea basin was located both east and north of the northeastern margin of the Siberian Platform (Egorov et al., 2001; Kontorovich et al., 2013; Kropachev, 2013; Makar'ev, 2013); therefore, the location of a source area east or north of it is hardly possible. The regular change in the isotope characteristics of the Permian terrigenous strata testifies to origin from the west; that might have been both the western Taimyr-Severnaya Zemlya fold-thrust belt and the fold-thrust belts of the basement of West Siberia or the southwestern and southern framings of the Siberian Platform. If the source areas were the fold-thrust belts of the basement of West Siberia and/or the southwestern and southern surroundings of the Siberian Platform, the transport of detritus requires a branched river network, whose existence was presumed before based on the study of the ages of detrital zircons (Ershova et al., 2015; Prokopiev et al., 2008, 2013). More precise location of the source area for the Permian terrigenous rocks requires additional studies.

Source areas of the Triassic terrigenous rocks. The observed increase in $\varepsilon_{\mathrm{Nd}}(t)$ in the Triassic rocks is expected, 


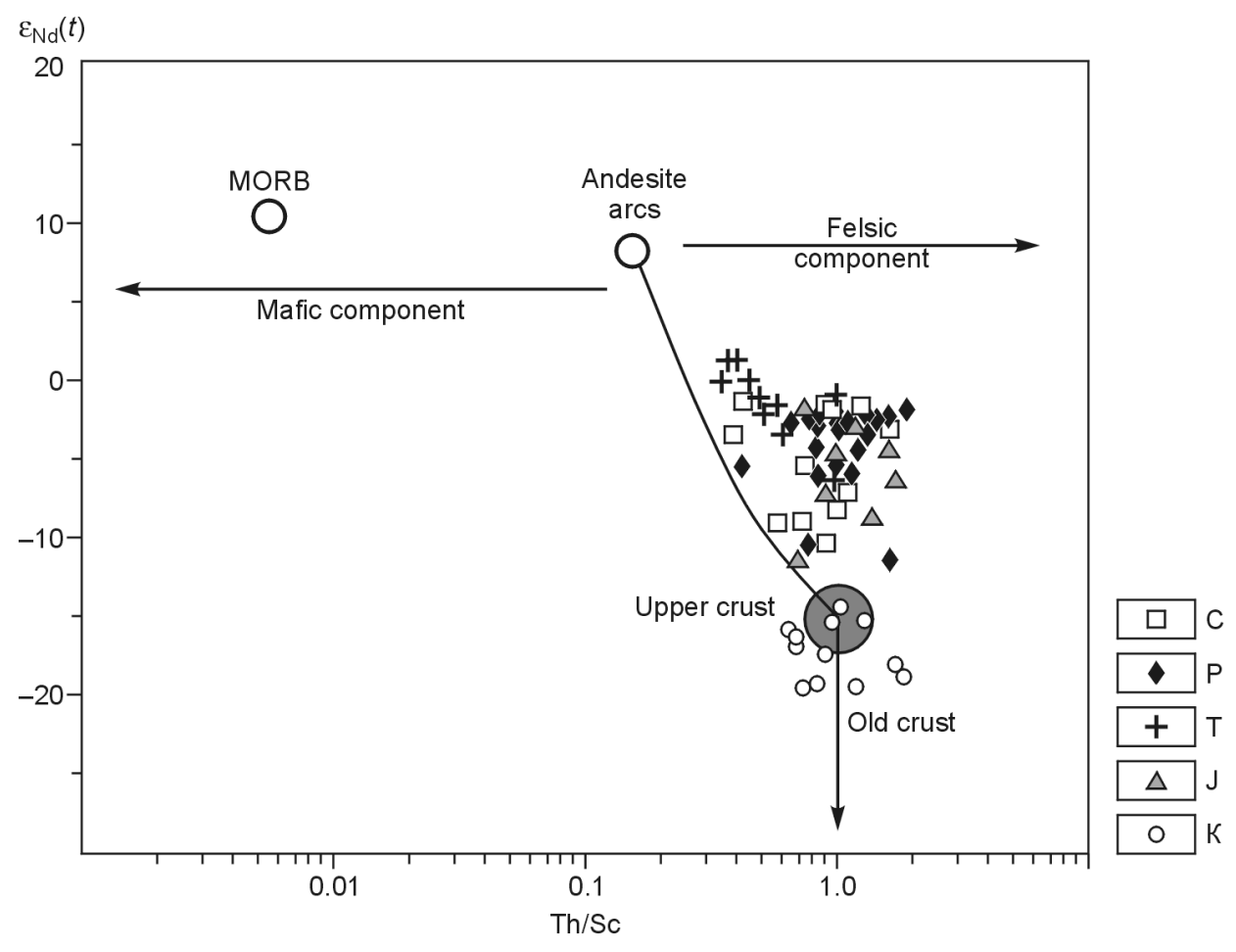

Fig. 7. The diagram $\varepsilon_{\mathrm{Nd}}(t)-\mathrm{Th} / \mathrm{Sc}$ for the studied samples (McLennan et al., 1993). Gray circle corresponds to the averaged composition of the upper crust.

and it reflects the formation and erosion of the igneous complex of the Siberian Traps (Fig. 8b). The isotope characteristics of the Triassic terrigenous rocks are nonuniform over the area, which testifies to the low degree of mixing of detritus and the proximity of source rocks. The lowest $\varepsilon_{\mathrm{Nd}}(t)$ values $(-6.5,-3.4$, and -2.2$)$ can be interpreted as the continuation of supply of material from the same source areas as in the Permian-Carboniferous or as a result of recycling of the underlying Permian and Carboniferous rocks. The high $\varepsilon_{\mathrm{Nd}}(t)$ values $(-1$ or more) in the Triassic terrigenous rocks suggest that a significant quantity of detritus with isotope characteristics similar to those of traps was supplied to the basin (Fig. 6). The small number of 230-260 Ma detrital zircons in the sample of Upper Triassic rocks from the northern margin of the Olenek uplift, where they make only 6 of 88 analyzed grains ((Miller et al., 2013), sample PROK-212), is explained by the fact that, compared to felsic igneous and metamorphic rocks, mafic rocks contain only an insignificant quantity of zircons, so that during the study of distribution of the ages of detrital zircons, their occurrence in the source area cannot be adequately estimated (McLennan et al., 1993).

Source areas of the Jurassic terrigenous rocks. In the Jurassic samples, the isotope characteristics of the sedimentary rocks change toward negative $\varepsilon_{\mathrm{Nd}}(t)$ values, which is particularly evident for the eastern part of the region, where the $\varepsilon_{\mathrm{Nd}}(t)$ values in the outcrops along the Lena River vary from -11.6 to -4.6 (Figs. 6, 8d, Tables 2, 3). Such a change in the isotope characteristics is explained by the decrease in the contribution of juvenile source areas, which were eroded in the Triassic, and the increase in the contribution of crustal source areas. The Upper Jurassic rocks have the lowest $\varepsilon_{\mathrm{Nd}}(t)$ values, which suggests the increase in the contribution of sources with mature continental crust over time. As the $\varepsilon_{\mathrm{Nd}}(t)$ values for the southeastern samples (Lena area) are lower than those for the northwestern ones (Olenek area), detritus with crustal isotope characteristics might have been transported from the southern Siberian Platform in the northward or northeastward direction. If the nearest basement salients (e.g., the Anabar Shield) had disintegrated, crustal sources would have influenced the isotope compositions of all the samples in the same way.

Source areas of the Cretaceous terrigenous rocks. At the Jurassic/Cretaceous boundary, the $\varepsilon_{\mathrm{Nd}}(t)$ values decreased dramatically and $\varepsilon_{\mathrm{Nd}}(t)$ in the Lower Cretaceous sedimentary rocks decreased to a value of -15 to -19 . Such $\varepsilon_{\mathrm{Nd}}(t)$ values are typical of the crystalline basement of the Siberian Platform, which was the main source of detritus (Figs. 6, 7, 8d). The change of the configuration of the source areas and the presence of new sources testify to important tectonic events both in and outside the study area. For example, in the Late Jurassic-Early Cretaceous, the Verkhoyansk foreland basin began to form; in the Early Cretaceous, the Lena-Anabar depression began to form and a transition from marine to continental sedimentation took place (Prokopiev et al., 2001).

The study of the $\mathrm{Nd}$ isotope composition of the Lower Cretaceous clastic rocks reveals minimum, if any, detritus removal from the fold-thrust belt. In the Verkhoyansk foldthrust belt, Carboniferous-Triassic terrigenous complexes are involved in the thrusting; in the case of their erosion, the $\varepsilon_{\mathrm{Nd}}(t)$ values in the Cretaceous sediments would be considerably higher than the actual ones. Moreover, if local source areas with higher $\varepsilon_{\mathrm{Nd}}(t)$ values influenced the basin under study, the 

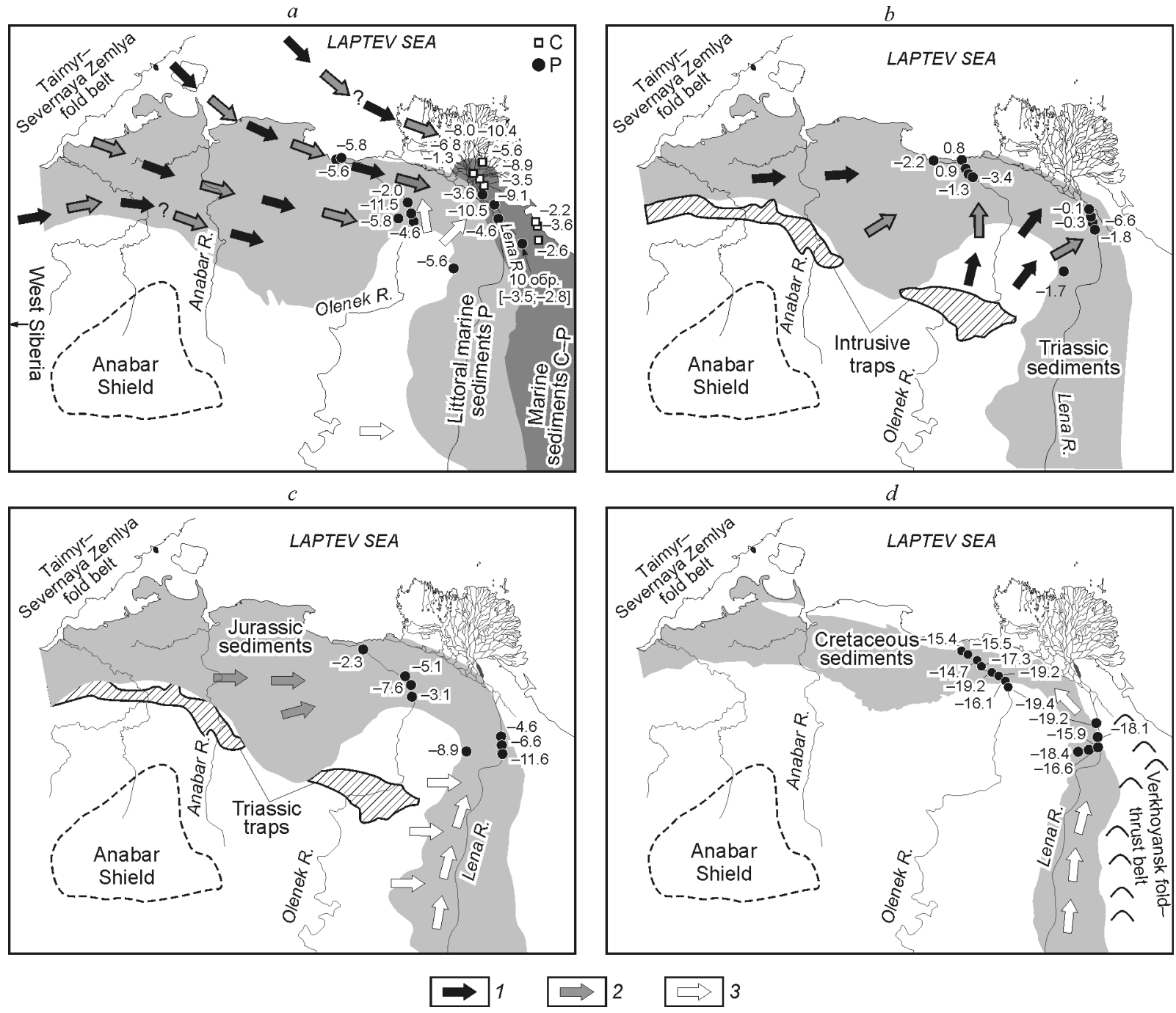

Fig. 8. Simplified scheme for the present-day distribution of the studied sedimentary complexes in the northeastern Siberian Platform and adjacent fold belts. Arrows show the generalized directions of transport of clastic ( 1 , island-arc and juvenile; 2 , mixed/uncertain; 3 , crustal) material: $a$, for the Carboniferous and Permian; $b$, for the Triassic; $c$, for the Jurassic; $d$, for the Cretaceous.

distribution of the isotope characteristics would not have been so uniform. Apparently, the mountains which formed in the Verkhoyansk fold-thrust complex were separated from the Verkhoyansk foreland basin by a front ridge as a barrier to the material supplied from the mountains. In that case material from the Verkhoyansk fold-thrust belt was transported eastward, and the Verkhoyansk foreland basin was filled with detritus predominantly from alternative source areas.

The transport of material from the west is possible, but this scenario is hardly likely, because the crystalline basement was overlain by a sedimentary cover (Prokopiev et al., 2001). The erosion of locally exposed low basement salients, such as the Anabar Shield or Olenek uplift, cannot have ensured the accumulation of $4 \mathrm{~km}$ thick strata of clastic sediments in the neighboring troughs. Therefore, the Verkhoyansk foreland basin and Lena-Anabar depression were filled, most likely, owing to the erosion of more distant parts of the Siberian Platform (e.g., the Aldan Shield). This hypothesis for the
Verkhoyansk foreland basin was previously put forward by O.V. Yapaskurt (1992).

\section{Conclusions}

The isotope-geochemical data presented in the paper show that the formation of the terrigenous sediments of the northeastern Siberian Platform in the Carboniferous proceeded owing to the erosion of mainly the Taimyr-Severnaya Zemlya fold-thrust belt, which is consistent with the dating of detrital zircons (Ershova et al., 2013, 2015; Prokopiev et al., 2013). In the Permian, detritus was transported, most likely, from the fold-thrust belts of the basement of the Siberian Platform, but additional studies are required for more definite conclusions. The erosion of traps played the leading role in the accumulation of the Triassic strata. The Upper Jurassic shallow-water marine and, particularly, Lower Cretaceous continental sediments filling the Verkhoyansk foreland basin and Lena-An- 
abar depression formed owing to the erosion of the crystalline basement (probably, the Aldan Shield). The dramatic difference in the isotope characteristics of the Carboniferous-Permian and Lower Cretaceous terrigenous rocks testifies to minor supply of the products of erosion of the Verkhoyansk fold-thrust belt during the formation of the latter.

We thank V.A. Vernikovsky and S.D. Sokolov, whose comments helped to significantly improve the paper.

The study was supported by TGS company, St. Petersburg State University (project no. 3.38.137.2014), the Russian Foundation for Basic Research (projects no. 13-05-00700 and 13-05-00943), and the Diamond and Precious Metal Geology Institute (project no. VIII.66.1.4).

\section{References}

Banner, J.L., 2004. Radiogenic isotopes: systematics and applications to earth surface processes and chemical stratigraphy. Earth Sci. Rev. 65, 141-194.

Boghossian, N.D., Patchett, P.J., Ross, G.M., Gehrels, G.E., 1996. Nd isotopes and the source of sediments in the miogeocline of the Canadian Cordillera. J. Geol. 104, 259-277.

Dagis, A.S., Kazakov, A.M., 1984. Stratigraphy, Lithology, and Cyclicity of Triassic Sediments in Northern Central Siberia [in Russian]. Nauka, Novosibirsk.

Degtyarev, K.E., 2012. Tectonic Evolution of Early Paleozoic Island-Arc Systems and Formation of the Continental Crust of the Caledonides of Kazakhstan. Trans. Geol. Inst. [in Russian]. GEOS, Moscow, Issue 602.

DePaolo, D.J., Wasserburg, G.J., 1976. Inferences about magma sources and mantle structure from variations of ${ }^{143} \mathrm{Nd} /{ }^{144} \mathrm{Nd}$. Geophys. Res. Lett. 3, 743-746.

Devyatov, V.P., Nikitenko, B.L., Shurygin, B.N., 2011. Jurassic Paleogeography of Siberia during the initiation of the main rearrangements. News Paleontol. Stratigr. Issues 16-17: Supplement to Russian Geology and Geophysics, 2011, Vol. 52, pp. 87-101.

Egorov, A.Yu., Surmilova, E.P., Galabal, R.O. (Eds.), 2001. State Geological Map of the Russian Federation [in Russian], Scale 1:1,000,000 (New Series). Explanatory Note. Sheet S-50-52. Bykovskii [in Russian]. Izd. Sankt-Peterburgsk. Kartfabriki VSEGEI, St. Petersburg.

Ershova, V.B., Holbrook, J., Khudoley, A.K., Prokopiev, A.V., 2010. Sequence stratigraphy of the Lower Cretaceous fluvial deposits of the Chekurovka area (NE Siberia, Lena River): preliminary results. EAGE, 4th St. Petersburg Int. Conf. Exhibition. St. Petersburg, Pap. A04.

Ershova, V.B., Khudoley, A.K., Prokopiev, A.V., 2013. Reconstruction of provenances and Carboniferous tectonic events in the North-East Siberian Craton framework according to $\mathrm{U}-\mathrm{Pb}$ dating of detrital zircons. Geotectonics 47 (2), 93-100.

Ershova, V.B., Prokopiev, A.V., Khudoley, A.K., 2015. Integrated provenance analysis of Carboniferous deposits from Northeastern Siberia: implication for the Late Paleozoic history of the Arctic. J. Asian Earth Sci. 109, 38-49.

GEOROC. Geochemistry of Rocks of the Oceans and Continents, http://georoc.mpch-mainz.gwdg.de.

Glebovitsky, V.A., Khil'tova, V.Ya., Kozakov, I.K., 2008. Tectonics of the Siberian Craton: Interpretation of geological, geophysical, geochronological, and isotopic geochemical data. Geotectonics 42 (1), 8-20.

Gusev, N.I., Rudenko, V.E., Berezhnaya, N.G., Skublov, S.G., Larionov, A.N., 2013. Isotope-geochemical characteristics and SHRIMP II age of metamorphic and igneous rocks in the Kotuikan-Monkholo zone of the Anabar Shield. Regional'naya Geologiya i Metallogeniya, No. 54, 45-59.

Jacobsen, S.B., Wasserburg, G.J., 1984. Sm-Nd evolution of chondrites and achondrites, II. Earth Planet. Sci. Lett. 67, 137-150.

Kaplan, M.E., 1976. Lithology of Mesozoic Marine Sediments in Northern East Siberia [in Russian]. Nedra, Leningrad.

Kazakov, A.M., Konstantinov, A.G., Kurushin, N.I., Mogucheva, N.K., Sobolev, E.S., Fradkina, A.F., Yadrenkin, A.V., Devyatov, V.P., Smir- nov, L.V., 2002. Stratigraphy of Petroleum Basins of Siberia. The Triassic System [in Russian]. Izd. SO RAN, Filial "Geo," Novosibirsk.

Khudoley, A.K., Prokopiev, A.V., 2007. Defining the eastern boundary of the North Asian craton from structural and subsidence history studies of the Verkhoyansk fold and thrust belt, in: Sears, J., Harms, T., Evenchick, C. (Eds.), Whence the Mountains? Enquiries into the Evolution of Orogenic Belts: A Volume in Honor of Raymond A. Price. GSA Spec. Pap. 433, 391-410.

Khudoley, A., Chamberlain, K., Ershova, V., Sears, J., Prokopiev, A., MacLean, J., Kazakova, G., Malyshev, S., Molchanov, A., Kullerud, K., Toro, J., Miller, E., Veselovskiy, R., Li, A., Chipley, D., 2015. Proterozoic supercontinental restorations: constraints from provenance studies of Mesoproterozoic to Cambrian clastic rocks, eastern Siberian Craton. Precambrian Res. 259, 78-94.

Knyazev, V.A., Devyatov, V.P., Shurygin, V.N., 1991. Early Jurassic Stratigraphy and Paleogeography of the Siberian Platform [in Russian]. YaNTs SO AN SSSR, Yakutsk.

Kontorovich, V.A., Kontorovich, A.E., Gubin, I.A., Zoteev, A.M., Lapkovsky, V.V., Malyshev, N.A., Soloviev, M.V., Fradkin, G.S., 2013. The Neoproterozoic-Phanerozoic section of the Anabar-Lena province: structural framework, geological model, and petroleum potential. Russian Geology and Geophysics (Geologiya i Geofizika) 54 (8), 980-996 (12531274).

Kovach, V.P., Kotov, A.B., Smelov, A.P., Starosel'tsev, K.V., Sal'nikova, E.B., Zagornaya, N.Yu., Safronov, A.F., Pavlushin, A.D., 2000. Evolutionary stages of the continental crust in the buried basement of the Eastern Siberian platform: Sm-Nd isotopic data. Petrology 8 (4), 353-365.

Kröner, A., Kovach, V., Belousova, E., Hegner, E., Armstrong, R., Dolgopolova, A., Seltmann, R., Alexeiev, D.V., Hoffmann, J.E., Wong, J., Sun, M., Cai, K., Wang, T., Tong, Y., Wilde, S.A., Degtyarev, K.E., Rytsk, E., 2014. Reassessment of continental growth during the accretionary history of the Central Asian Orogenic Belt. Gondwana Res. 25, 103-125.

Kropachev, A.P. (Ed.), 2013. State Geological Map of the Russian Federation [in Russian], Scale 1 : 1,000,000 (Third Generation). Explanatory Note. Ser. Anabaro-Vilyuiskaya. Sheet R-51. Dzhardzhan [in Russian]. Izd. Sankt-Peterburgsk. Kartfabriki VSEGEI, St. Petersburg.

Kuptsova, A.V., Khudoley, A.K., Molchanov, A.V., 2011. Lithogeochemistry of Upper Proterozoic terrigenous sediments in the southern East Anabar basin: evolution of the composition of source rocks and secondary alterations. Vestnik Sankt-Peterburgsk. Gos. Univ., Ser. 7, Geologiya i Geografiya, No. 1, 17-31.

Lightfoot, P.C., Hawkesworth, C.J., Hergt, J., Naldrett, A.J., Gorbachev, N.S., Fedorenko, V.A., Doherty, W., 1993. Remobilisation of the elemental lithosphere by a mantle plume: major-, trace-element, and $\mathrm{Sr}-$, $\mathrm{Nd}-$, and $\mathrm{Pb}$-isotope evidence from picritic and tholeiitic lavas of the Noril'sk District, Siberian Trap, Siberia. Contrib. Mineral. Petrol. 114, 171-188.

Makar'ev, A.A. (Ed.), 2013. State Geological Map of the Russian Federation [in Russian], Scale $1: 1,000,000$ (Third Generation). Explanatory Note. Sheet T-45-48. Cape Chelyuskin [in Russian]. Izd. Sankt-Peterburgsk. Kartfabriki VSEGEI, St. Petersburg.

McLennan, S.M., Hemming, S., McDaniel, D.K., Hanson, G., 1993. Geochemical approach to sedimentation, provenance, and tectonics, in: Johnson, M.J., Basu, A. (Eds.), Processes Controlling the Composition of Clastic Sediments. GSA Spec. Pap. 284, 21-40.

McLennan, S.M., Bock, B., Hemming, S.R., Hurowitz, J.A., Lev, S.M., McDaniel, D.K., 2003. The role of provenance and sedimentary processes in the geochemistry of sedimentary rocks, in: Geochemistry of Sediments and Sedimentary Rocks: Evolutionary Considerations to Mineral DepositForming Environments. St. John's: Geol. Assoc. Canada, pp. 7-38.

Mezhvilk, A.A., Markov, F.G. (Eds.), 1983. Geological Map of the Soviet Union [in Russian], Scale 1 : 1,000,000. Explanatory Note. Sheet R-(50)-52. Tiksi [in Russian]. Ministerstvo Geologii SSSR, Leningrad.

Michard, A., Gurriet, P., Soudant, M., Albarede, F., 1985. Nd isotopes in French Phanerozoic shales: external vs. internal aspects of crustal evolution. Geochim. Cosmochim. Acta 49, 601-610.

Miller, E.L., Soloviev, A.V., Prokopiev, A.V., Toro, J., Harris, D., Kuzmichev, A.B., Gehrels, G.E., 2013. Triassic river systems and the paleo-Pacific margin of northwestern Pangea. Gondwana Res. 23, 1189-1664. 
Molchanov, A.V., Knyazev, V.Yu., Khudoley, A.K., 2011. Tectonic-fluid zones of the Anabar Shield and their ore content. Regional'naya Geologiya i Metallogeniya, No. 47, 96-106.

Parfenov, L.M., 1984. Mesozoic Continental Margins and Island Arcs of Northeastern Asia [in Russian]. Nauka, Novosibirsk.

Podkovyrov, V.N., Kotova, L.N., Kotov, A.B., Kovach, V.P., Graunov, O.V., Zagornaya, N.Yu., 2007. Provenance and source rocks of Riphean sandstones in the Uchur-Maya region (east Siberia): Implications of geochemical data and Sm-Nd isotopic systematics. Stratigr. Geol. Correl. 15 (1), 41-56.

Prokopiev, A.V., Parfenov, L.M., Tomshin, M.D., Kolodeznikov, I.I., 2001. The cover of the Siberian Platform and adjacent fold-thrust belts, in: Tectonics, Geodynamics, and Metallogeny of the Sakha Republic (Yakutia) [in Russian]. MAIK "Nauka/Interperiodica," Moscow, pp. 113-155.

Prokopiev, A.V., Toro, J., Miller, E.L., Gehrels, G.E., 2008. The paleo-Lena River-200 m.y. of transcontinental zircon transport in Siberia. Geology 36, 699-702.

Prokopiev, A.V., Ershova, V.B., Miller, E.L., Khudoley, A.K., 2013. Early Carboniferous paleogeography of the northern Verkhoyansk passive margin as derived from $\mathrm{U}-\mathrm{Pb}$ dating of detrital zircons: role of erosion products of the Central Asian and Taimyr-Severnaya Zemlya fold belts. Russian Geology and Geophysics (Geologiya i Geofizika) 54 (10), 1195-1204 (1507-1529).

Proskurnin, V.F., Vernikovsky, V.A., Metelkin, D.V., Petrushkov, B.S., Vernikovskaya, A.E., Gavrish, A.V., Bagaeva, A.A., Matushkin, N.Yu., Vinogradova, N.P., Larionov, A.N., 2014. Rhyolite-granite association in the Central Taimyr zone: evidence of accretionary-collisional events in the Neoproterozoic. Russian Geology and Geophysics (Geologiya i Geofizika) 55 (1), 18-32 (23-40).

Rogov, M.A., Zakharov, V.A., Ershova, V.B., 2011. Detailed stratigraphy of the Jurassic-Cretaceous boundary beds of the Lena River lower reached based on ammonites and Buchiids. Stratigr. Geol. Correl. 19 (6), 641-662.

Romanova, I.V., Vernikovskaya, A.E., Vernikovskii, V.A., Matushkin, N.Yu., Larionov, A.N., 2012. Neoproterozoic alkaline magmatism and associated igneous rocks in the western framing of the Siberian craton: petrography, geochemistry, and geochronology. Russian Geology and Geophysics (Geologiya i Geofizika) 53 (11), 1176-1196 (1530-1555).

Rosen, O.M., Levskii, L.K., Zhuravlev, D.Z., Rotman, A.Ya., Spetsius, Z.V., Makeev, A.F., Zinchuk, N.N., Manakov, A.V., Serenko, V.P., 2006. Paleoproterozoic accretion in the Northeast Siberian craton: Isotopic dating of the Anabar collision system. Stratigr. Geol. Correl. 14 (6), 581-601.

Ross, G.M., Gehrels, G.E., Patchett, P.J., 1997. Provenance of Triassic strata in the Cordilleran miogeocline, western Canada. Bull. Can. Petrol. Geol. 45, 461-473.
Ross, G.M., Patchett, P.J., Hamilton, M., Heaman, L., DeCelles, P.G., Rosenberg, E., Giovanni, M.K., 2005. Evolution of the Cordilleran orogen (southwestern Alberta, Canada) inferred from detrital mineral geochronology, geochemistry, and Nd isotopes in the foreland basin. GSA Bull. 117, 747-763.

Rytsk, E.Yu., Kovach, V.P., Kovalenko, V.I., Yarmolyuk, V.V., 2007. Structure and evolution of the continental crust in the Baikal Fold Region. Geotectonics 41 (6), 440-464.

Shurygin, B.N., Nikitenko, B.L., Devyatov, V.P., Il'ina, V.I., Meledina, S.V., Gaideburova, E.A., Dzyuba, O.S., Kazakov, A.M., Mogucheva, N.K., 2000. Stratigraphy of Petroleum Basins of Siberia. The Jurassic System [in Russian]. Izd. SO RAN, Filial "Geo," Novosibirsk.

Smelov, A.P., Timofeev, V.F., 2007. The age of the North Asian cratonic basement: An overview. Gondwana Res. 12, 279-288.

Smelov, A.P., Zedgenizov, A.N., Timofeev, V.F., 2001. Basement of the North Asian craton, in: Tectonics, Geodynamics, and Metallogeny of the Sakha Republic (Yakutia) [in Russian]. MAIK "Nauka/Interperiodica," Moscow, pp. 81-112.

Smelov, A.P., Kotov, A.B., Sal'nikova, E.B., Kovach, V.P., Beryozkin, V.I., Kravchenko, A.A., Dobretsov, V.N., Velikoslavinskii, S.D., Yakovleva, S.Z., 2012. Age and duration of the formation of the Billyakh tectonic melange zone, Anabar shield. Petrology 20 (3), 286-300.

Taylor, S.R., McLennan, S.M., 1985. The Continental Crust: Its Composition and Evolution. Blackwell, Oxford.

Vernikovskaya, A.E., Pease, V.L., Vernikovsky, V.A., Gee, D.G., Travin, A.V., 2002. Geochemistry and petrology of Neoproterozoic granites of the Mamont-Shrenk Terrane, Central Taimyr. Geochem. Int. 40 (5), 435-446.

Vernikovsky, V.A., 1996. Geodynamic Evolution of the Taimyr Folded area [in Russian]. Izd. SO RAN, NITs OIGGM, Novosibirsk.

Vernikovsky, V.A., Pease, V.L., Vernikovskaya, A.E., Romanov, A.P., Gee, D.G., Travin, A.V., 2003. First report of early Triassic A-type granite and syenite intrusions from Taimyr: product of the northern Eurasian superplume? Lithos 66, 23-36.

Vernikovsky, V.A., Vernikovskaya, A.E., Pease, V.L., Gee, D.G., 2004 Neoproterozoic Orogeny along the margins of Siberia. Geol. Soc. London Memoir 30, 233-248.

Vernikovsky, V.A., Vernikovskaya, A.E., Wingate, M.T.D., Popov, N.V., Kovach, V.P., 2007. The 880-864 Ma granites of the Yenisey Ridge, western Siberian margin: Geochemistry, SHRIMP geochronology, and tectonic implications. Precambrian Res. 154, 175-191.

Yapaskurt, O.V., 1992. Lithogenesis and Mineral Resources of Miogeosynclines [in Russian]. Nedra, Moscow.

Editorial responsibility: V.A. Vernikovsky 